\title{
ETNOCENTRISM AND CRITICAL THEORY TWO CASES: UNITED STATES AND MEXICO
}

\author{
ETNOCENTRISMO E TEORIA CRÍTICA: \\ DOIS CASOS: ESTADOS UNIDOS E MÉXICO \\ ETNOCENTRISMO Y TEORÍA CRÍTICA: \\ DOS CASOS: ESTADOS UNIDOS Y MÉXICO
}

STEFAn GANDLER ${ }^{\mathrm{I}}$

\begin{abstract}
How is it possible to understand a specific cultural determination of human praxis, especially the productive and consumptive one, without falling into ethnologising human subjects in their everyday forms of reproduction, or constructing biological fixations? The former senior faculty of the Universidad Nacional Autónoma de México (UNAM) Bolívar Echeverría (Riobamba, Ecuador 1941 - Mexico City 2010), who does not limit human culture to its 'elevated' forms and bases his analysis in the precise manner of material reproduction, finds an adequate image of this relationship between freedom and tradition, between individuality and a historically - and geographically - determined collectivity. This image lies in human languages, their innumerable speech acts and in a science that studies the relation of interdependence among them: semiology.
\end{abstract}

Keywords: Critical theory; Semiology; MarXism; Quadruple ethos, CAPITAlist modernITY, LINGUISTICS, USE VALUE.

RESUMO Como é possível compreender uma determinação cultural específica da praxis humana, especialmente a produtiva e a consumista, sem cair em assuntos humanos etnológicos, em suas formas cotidianas de reprodução, ou construção de fixações biológicas? A antiga faculdade sénior da Universidade Nacional Autônoma do México (UNAM) Bolívar Echeverría (Riobamba, Equador 1941 - Cidade do México 2010), que não limita cultura humana às suas formas "elevadas" e baseia sua análise na maneira precisa de reprodução material, encontra uma imagem adequada dessa relação entre Liberdade e tradição, entre individualidade e uma determinação historicamente e geograficamente determinada pela

Universidade Autônoma de Querétaro (UAQ), México. 
coletividade. Esta imagem reside em linguagens humanas, seus inúmeros atos de fala e em uma ciência que estuda a relação de interdependência entre eles: semiologia.

Palavras-chave: Teoria Crítica, Etnocentrismo, Estados Unidos, México

Resumen Como es posible encontrar una determinación cultural específica de la praxis humana, especialmente una productiva y un consumista, sin caer en ciegos humanos y nológicos, en sus formas cotidianas de reproducción, o construcción de reparaciones biológicas? La antigua universidad senior de la Universidad Nacional Autónoma de México (UNAM) Bolívar Echeverría (Riobamba, Ecuador 1941 - Ciudad de México 2010), que no limita cultura humana a sus formas "elevadas" y basa su análisis en la manera precisa de material de reproducción, encuentra una imagen de acuerdo con la relación entre libertad y la tradición, entre individualidad y una determinación históricamente y geográficamente determinada por la colectividad. Esta imagen reside en lenguajes humanos, sus innumerables actos de habla y en una ciencia que estudia una relación de interdependencia entre ellos: semiología.

Palabras clave: Teoría Crítica, Etnocentrismo, Estados Unidos, México

In order to understand the specific way of confronting conceptually Marxism and semiology as Bolívar Echeverría (Riobamba, Ecuador 1941 - Mexico City 2010) is doing in his work, his semiology approach should be understood as polemical. In interpreting the production and consumption of use values as the main semiology system, he is bringing to a halt those theoretical currents which declare spoken language to be the most important of human sign systems. Echeverría is liberating semiology from the subordination into which it has fallen, after de Saussure, at the hands of linguistics, becoming a simple supplier of the latter.

In recent years, Latin America has begun in the social plane to distance itself from worldwide loci of power, reorganizing economic and political relations; this trend, however, is hardly visible in the field of social philosophy. It is now urgent to reorganize the international philosophical and social-sciences discussion, using Critical Theory as its starting point. Critical Theory is one of the few existing social theories with the ability to develop and reconstruct the remains of the capability for auto-critique in the existing world society. A result of this theoretical reorganization could be to overcome the ongoing dominance of philosophical Eurocentrism; a dominance that actually is no less virulent than it was in the times of the Colonialism. Only through an open and non-Eurocentric reorganization of the international discussion on social theory and philosophy, will it be possible to give society the conceptual tools it needs in order to leave the state of reflective stagnation it has been trapped in for over the past three decades. This stagnation, reflected in our inability to leave behind the so-called neoliberal ideology, has propelled us into going about our everyday lives in a world where both the social and ecological consequences of this ideology are becoming irreversible.

Critical Theory, originally developed by the Frankfurt School in the 1920's and 30's, 50 's and 60 's, has a certain decisive flaw it shares with the vast majority of other European

34 Comunicações | Piracicaba | v. 24 | n. 2 | p. 33-56 | maio-agosto 2017 
philosophies, as well. Namely, it contains within it a trend towards generalizing its place of origin in two distinct ways. First, it only considers theories originating from the European continent as 'fundamental,' and second, it only takes the social realities of Europe and the United States into account. Despite this crucial limitation, however, we remain profoundly convinced that this school of thought is the only way in which to correctly interpret the 'real' world. In addition to needing new input in order to do so, however, we also need a way to overcome the problem of Eurocentrism earlier described.

In the tradition of the Frankfurt School, the key concept needed to understand the specific dynamics of the formation of consciousness (partially formed by the collective unconscious and also the spontaneous forms of organization in collective life) is that of reification, inherited from George Lukács' The History of Class Consciousness, especially the text Reification and the Consciousness of the Proletariat. Despite the vast relevance of this work for understanding capitalist society, one of its foremost disadvantages is in its inability to significantly describe the breadth of forms of everyday life that underlie capitalist reproduction. In a certain sense, we can see the concept of 'reification' as something which captures a specifically prevalent form in North-Western Europe, one which Bolívar Echeverría, former philosophy professor at the UNAM, who passed away four years ago, conceives as the 'realist ethos.' - It is because of reification that one is unable to perceive of the inherent contradictions in social forms today. In turn, it redefines them as 'things' which are unquestionable, eternal and no longer subject to change. The 'baroque ethos', on the other hand, allows one both to perceive of and live with these contradictions without negating or denying them; unlike the realist ethos, it plays with them and, in a certain sense, refunctionalizes them. (Hence, certain social phenomena arise out of the 'baroque ethos,' such as a permanent suspicion of possible corruption, that is then combined with the belief that without this corruption, things may become even more complicated, or the use of double-speak and ironic plays with language etc.) On the one hand, what Echeverría calls the 'baroque ethos,' which in Latin America and Mexico coexists with the 'realist ethos,' is not adequately acknowledged by classical critique of ideology based solely upon the concept of reification; on the other, we can note - for further discussions - that Echeverría's theory of the historical ethe pays a certain price for the contributions it makes, thereby falling prey to some of the limitations that have actually been overcome by the critique of ideology.

$* * *$

In order to open the necessary international debate on a possible reconstruction of Critical Theory, starting from contributions made outside the self-called first world, we discuss in the following lines one of the central theoretical contributions of the Ecuadorian-Mexican philosopher Bolívar Echeverría (1941-2010)who, in our way of analyzing the today's international philosophical debate, is one of the most important authors in the tradition of the Frankfurt School, even when he was born and died outside the economical and military centres of our brave and wonderful world: the relationship between use-value and 
communication, which is the conceptual base of his above mentioned theory of the four ethe of capitalist modernity. Echeverría set himself a task that cannot be resolved easily. $\mathrm{He}$ wanted to provide a concrete content to the concept of praxis, and thereby to grasp it in its historical dimension. According to all indications, the problem consists of the following: if the concept of praxis is inseparably linked to the concept of the (autonomous) subject who freely decides, then how can this be understood as something determinate, with concrete content? How can we theoretically reproduce this complex ensemble of particular subjective decisions on the basis of historical-concrete conceptual determinations, which must necessarily seek out the general?

Or, to put it differently, and more closely in line with the materialist theory of culture toward which Echeverría aspires: how is it possible to understand a specific cultural determination of human praxis, especially the productive (and consumptive) one, without falling into ethnologising human subjects in their respective everyday forms of reproduction, or even construct biological fixations? Echeverría, who, as we have said, does not limit human culture to its 'elevated' forms - for example, art at a gallery - and bases his analysis, rather, in the precise manner of material reproduction (as the unity of production and consumption), finds an adequate image of this relationship between freedom and tradition, between individuality and a historically - and geographically -determined collectivity. This image lies in human languages and their innumerable speech acts and in a science that studies the relation of interdependence among them: semiology, founded by Ferdinand de Saussure. To do so, he refers to authors like Roman Jakobson and Louis Hjelmslev. ${ }^{1}$

In his article "La 'forma natural' de la reproducción social", he does so through the use of not only text, but also, on average every two pages, graphics with schematic representations of the processes of communication and reproduction which, no doubt, allow us to grasp their similarity visually. We should not overlook his affinity for Saussure's figures, although Echeverría's are much more complex and can only be understood after a meticulous study of the primary text in question. Here, what is crucial is the fact that Echeverría does not refer to semiology in order to grasp all reality as a mere sign and thereby to see history only as an 'unfinished text', but the opposite. Not only does he want to demonstrate that the first and fundamental human sign system is, in every case, that of the various forms of producing and consuming use values, but he wants to show even more than this: for Echeverría, the communication process is a dimension of the process of reproduction.

"So I make visible a parallel between the process of reproduction and that of communication. ... That is to say, the latter (the process of communication) is an aspect, a dimen-

\footnotetext{
Bolívar Echeverría emphasises the importance of these two authors in his study of the natural form: "To a certain degree I approximated above all Jakobson and Hjelmslev, they are the two that I treat as crucial in questions of semiology and linguistics" (Interview with Bolívar Echeverría, 11 September 1996, in the Faculty of Philosophy and Arts of the UNAM. In the absence of a unified counting method, the tape position is indicated according to the apparatus utilised (Panasonic 608), here: cassette I, side A, pos. 247-50 [cited hereafter as Interview with Bolívar Echeverría].)

In so doing, he draws support from Jakobson 1960, Jakobson 1971 and Hjelmslev 1971, p. 55. See Echeverría 1984, pp. 42, 3, and 40).
}

36 Comunicações $\mid$ Piracicaba $\mid$ v. $24 \mid$ n. $2 \mid$ p. 33-56 $\mid$ maio-agosto 2017 
sion of the former [which is to say, the process of reproduction]"; ${ }^{2}$ that is, the process of reproduction can be compared to the process of communication not because the world as a totality can only be grasped as a complicated combination of 'texts' and 'ways of reading', but the reverse; communication, as the unity of the production and consumption of signs, is in itself one among many productive and consumptive acts that human beings must undertake in order to be able to organise and maintain their lives, but it is in no way the fundamental form and always has an inevitable materiality as its foundation.

Speech [el lenguaje] $]^{3}$ in its basic, verbal realisation is also a process of the production/consumption of objects. The speaker presents to the listener a transformation of nature: his voice modifies the acoustic state of the atmosphere, and this change, this object, is perceived or consumed as such by the ear of the other. (ECHEVERRÍA, 1984: 45.) ${ }^{4}$

Bolívar Echeverría is concerned with explaining the process of producing and consuming use values through reference to the theoretical contributions of semiology, but without denying the primacy of nature and the primacy of the material as the inalienable foundation of the ideal. Here, we find an essential difference vis-à-vis a series of contemporary approaches which are caught up in the concept of communication (or related conceptions, for example that of "articulation"), and who see in it the most diverse forms, real or imagined, the explanation, and, at the same time, the salvation of the world.

While Saussure subordinates linguistics to semiology sémiologie $^{5}$ and realises that knowledge of the "true nature of language" is only possible if it is correctly classified under the most general field of "all other systems of the same order [tous les autres systèmes du meme ordre]"6 which semiology studies, Echeverría seeks to classify semiology (understood by him as the production and consumption of signs) under the even broader field of

2 Interview with Bolívar Echeverría, cassette 1, side A, pos. 264-7.

3 Evidently, by "lenguaje" ["speech"] Echeverría understands what Ferdinand de Saussure (who he cited at various points in the text here analysed) calls "langage" Saussure also uses this term as a synonym for "faculté de langage," and explains: "l'exercice du langage repose sur une faculté que nous tenons de la nature". (SAUSSURE, 1979). English translation: "the use of speech is based on a natural faculty" (SAUSSURE, 1966: 9).

Saussure already indicates here that we should understand by "langage" ["speech" in English, "lenguaje" in Spanish] not only the languages ["langue" in French, "lengua" in Spanish] spoken, but also the totality of all possible forms of expression or also of forms of exteriorisation; it should be used to refer to any systematisation or homogenisation of any forms of expression. Note: "Whereas speech is heterogeneous, language, as defined, is homogeneous ... Language, once its boundaries have been marked off within the speech data, can be classified among human phenomena, whereas speech cannot" (SAUSSURE, 1966: 15) Compare also: "faculty of speech" (SAUSSURE, 1966: 10).

4 Echeverría refers here to Troubetzkoy, 1970: 38.

5 "Linguistics is only a part of the general science of semiology; the laws discovered by semiology will be applicable to linguistics, and the latter will circumscribe a well-defined area within the mass of anthropological facts" (SAUSSURE, 1966: 16).

6 Note: "But to me the language problem is mainly semiological, and all developments derive their significance from that important fact. If we are to discover the true nature of language we must learn what it has in common with all other semiological systems" (SAUSSURE, 1966: 17). 
production and consumption in general. It is clear that Saussure and Echeverría differ notably from one another, since Saussure considers semiology to be embedded within social psychology, and this, in turn, within psychology in general, while Echeverría's system of reference is the critique of political economy. ${ }^{7}$ We can find a parallel between the two, since in order to study the most general object, that which is necessary for the understanding of particulars, they both set out from the most complex among particular objects. Hence Saussure writes:

\begin{abstract}
Signs that are wholly arbitrary realize better than the others the ideal of the semiological process; that is why language, the most complex and universal of all systems of expression, is also the most characteristic; in this sense linguistics can become the master-pattern for all branches of semiology although language is only one particular semiological system (SAUSSURE, 1966: 68).
\end{abstract}

Here, what attracts our attention - despite all of the differences - is a degree of similarity with Marx's methodological procedure, clearly summarised in the phrase: "The anatomy of the human being is the key to the anatomy of the ape" (MARX, 1904: 300). Formulated differently: Saussure's method reminds us of the Marxian distinction between the trajectory of research and the trajectory of explanation, which, for example, in the case of Capital, move to a large extent in opposite directions. Echeverría, who as we have seen wants to link Marx with semiology, also seeks to employ a similar method in his research. For the analysis of the general fact of the production and consumption of objects, he refers largely to the production/consumption of signs. He does not choose this approach because the latter are more important than other forms of production/consumption, but quite simply because it is in these that we can grasp something general, and moreover because the production/consumption of anything, and above all with reference to use value, always contains a production/consumption of signs.

Once this has been clarified, we must state the fact that there is a broad presence of communicative elements in material reproduction itself. On this point, one could feel tempted to say lightly: "naturally, since to organise the process of reproduction it is necessary to communicate, it is necessary to discuss projects, to resolve problems orally and to carry out other linguistic acts". While this is correct, it is not the central aspect of Echeverría's understanding of how similar and interwoven reproduction and communication are. Rather, he sees in the very production and consumption of these use values an

\footnotetext{
"A science that studies the life of signs within society is conceivable; it would be a part of social psychology and consequently of general psychology; I shall call it semiology (from Greek sēmîon 'sign')" (SAUSSURE, 1966: 16). Elsewhere he speaks not of "social psychology" but "group psychology" (SAUSSURE, 1966: 78). Note that Saussure implicitly understands social psychology as a science whose object is "society" ["la vie sociale"].

So what interests Saussure is to establish the semiology he has founded within the social sciences, with the only limitation being that he here thinks about above all social psychology, which is to say, he seems to see society first of all determined by one aspect of those dynamics that Marx calls "ideological forms", distinguishing them from the "economic conditions of production, which can be determined with the precision of natural science" (see MARX, 1904: 12)
}

38 Comunicações | Piracicaba $\mid$ v. $24 \mid$ n. $2 \mid$ p. 33-56 | maio-agosto 2017 
act of "communication", ${ }^{8}$ and possible the most decisive communicative act for social life itself. For example, to prepare a meal and the following act of eating it is, at the same time, to produce a determinate sign and to interpret it.

To produce and consume objects is to produce and consume meanings [significaciones]. To produce is to communicate [mitteilen], to propose a use value of nature to someone else; to consume is to interpret [auslegen], to validate this use value that another has found. To appropriate nature is to make it meaningful [significativa]. (ECHEVERRÍA, 1984: 42). ${ }^{9}$

We find, here, an important difference with regard to the production of value, which tendentially can leave aside the real satisfaction of human needs, if only the creation of value and with it surplus value remains guaranteed. The catch lies in the fact that, after all, the production of value cannot completely refrain from the production of use value, which is its "natural" foundation. It is from this point, for Echeverría, that the possibility of overcoming the apparently eternal capitalist mode of production emerges. In his theories, Marx based his hopes for putting an end to the ruling relations - without the disappearance of the subjects who uphold them - on the fact that the current social formation cannot exist without proletarians, and yet they are the potential revolutionary subject. In contrast with this view, Echeverría is not fixated exclusively on production. His point of departure lies more in the unity of production and consumption, and with it, in the unity of the production of value and the production of use value, since it is only in consumption that we can determine if an object effectively has use value and with it value as well (which Marx formulates succinctly when he says that a product must realise its value in the market). ${ }^{10}$ It is only a product's use-value that makes it possible for it to be really consumed and, therefore, to be bought in the first place. Thus, Echeverría, inspired by Marx, takes as his starting point the fact that the production of value does not proceed without the production of use value, but rather that it simultaneously and by necessity controls, oppresses to an increasing degree, and tends toward the destruction of that use value. This antagonistic contradiction inherent to the capitalist mode of production gives him some indication of a possible way out. Dogmatic, Soviet-style Marxism presumed that the way out lay in simply overcoming shortages of working-class consumer products, to be accomplished through a massive and

8 Already in his earliest works, Echeverría suggests the importance of other types of "languages" distinct from commonplace ones. However, in so doing he does not refer to economic praxis, as in his more recent works, but rather to political praxis. See, in this regard: "For the guerrilla discursive propaganda is essential, but this arrives afterward, when it can fall upon fertile soil" (ECHEVERRÍA, 1968: 16-7).

It is clear that these formulations are separated by a chasm from the idea of a 'coercion-free discourse' or anything of the sort.

9 Here, Echeverría refers to the following text: Leroi-Gourham, 1964: 163.

10 "Hence commodities must be realised as values before they can be realised as use-values. On the other hand, they must stand the test as use-values before they can be realised as values. For the labour expended on them only counts in so far as it is expended in a form, which is useful for others. However, only the act of exchange can prove whether that labour is useful for others, and its product consequently capable of satisfying the needs of others" (MARX, 1976: 179-80). 
continuous increase in the productive forces, which in theory entailed a narrow productivism, a naïve progressivism, and the most brutal methods for increasing productivity under Stalinism. ${ }^{11}$ Echeverría, like the majority of the thinkers of Western Marxism, believed that in quantitative terms, the question of supplying all human beings is one which was long since easily accomplishable through the deployment of a relatively limited amount of labour. According to him, the problem lies not in the quantitative, but in the qualitative: what is produced and how it is produced, or in other words, the question of production and consumption insofar as these refer to use value:

Only the reconstruction of the critical and radical concept of use-value can demonstrate the absence of a basis for that identification of Marxism with Western productivism, the economistic progressivism of capitalism, and bourgeois political statism (ECHEVERRÍA, 1984: $34 \mathrm{n}$ 4). ${ }^{12}$

In this passage, two themes are touched when Echeverría makes a critique of the "identification of Marxism with Western productivism"; in the first place, he indicates the need for a critique of Eurocentrism, something which mostly has not been surmounted on the Left, even in important sectors of the non-dogmatic Left. Even the terminology of 'developed' and 'underdeveloped' countries - naïvely taken up all too often - expresses a deeply-rooted economistic productivism which underhandedly elevates the productive forces and its technical-industrial perfection (in the sense of being competitive under capitalist conditions) to the characteristic of 'development' in general. At the same time, this includes the presumption of a 'natural' need for a constant further development of the productive forces in the previously indicated sense (moreover, in very determined ways), which, however, is an unavoidable necessity exclusively under ruling social conditions. In the framework of this logic, then, some countries are 'more developed' than others, but the resulting hierarchisation of the world acquires a life of its own and continues to function even in the heads of critics of the capitalist mode of production. (In a certain sense, Eurocentrism is more problematic on the Left than in conservative theory. For conservatives, Eurocentrism emerges necessarily from their uncritical reflection on power relations; on the Left, on the contrary, it can only be explained as an ideological remnant of cultural chauvinism). ${ }^{13}$

${ }_{11}$ Observe also, in this respect, the powerfully Eurocentric tendency of Stalinism, in which the scarce efforts (by Lenin, above all) in the first post-revolutionary years to eliminate or soften racist oppression toward the non-Russian inhabitants of the Soviet Union (efforts which materialised as a degree of sovereignty, in particular autonomous regions under the banner of different nationalities), were practically abandoned, restoring the Tsarist model of Russian control over the entire territory.

12 The cited phrase continues: "[an identification] that led K. Korsch in 1950 ... to raise again, for the second half of the century, the theme, vulgarised in the 70s, of the inadequacy of Marxist discourse for the requirements of the new historical form of the revolution". Echeverría is here referring to " 10 Thesen über Marxismus heute" (KORSCH, 1965: 89,90).

13 In this Echeverría can be distinguished - despite all the similarities - from Western Marxism and the Frankfurt School. Thus, for example, while the critique and analysis of Dialectic of Enlightenment admittedly mentions "European civilisation" as the central object of the investigation, its ethnocentric character is not taken as a theme. (HORKHEIMER and ADORNO, 2002: 9). Neither in its scientific behaviour or its interests has the Frankfurt School been able to remove itself from common Eurocentric prejudice, and it has largely ignored authors from the so-called Third World.

40 Comunicações | Piracicaba | v. 24 | n. 2 | p. 33-56 | maio-agosto 2017 
Secondly, this passage cited from Echeverría contains, moreover, an implicit response to a philosopher whose work kept our author occupied during many years of his youth. When Echeverría insists that Marx does not constitute an integral part of "Western" thought, but that the concept of use value "necessarily moves beyond Western metaphysics" (ECHEVERRÍA, 1984: 35 n 4) we are dealing with an unequivocal rejection of Martin Heidegger's assertion, that Karl Marx is the ultimate representative of Western metaphysics.

With regard to the question of how we can think the relationship between subject and object as profoundly marked by determination (by the laws of nature, for example), as well as and at the same time by human freedom, we can sketch out Echeverría's effort to approach the question in the following terms. As indicated, it is possible to trace the parallel between the processes of reproduction and communication without de-materialising the former or reinterpreting it idealistically. But in the process of communication we find the peculiarity of this same singular coexistence of freedom and new creation in each speech-act and the simultaneous determination by the language in which the communication occurs in each case. It is only because in each moment a new speech act with a certain degree of freedom is created that the speaker can more or less correspond to each constellation that he should capture. But at the same time, he only can make himself understood to another, because he moves within the respective language and broadly accepts its rules.

Something similar can be said of the production and consumption of use values. The producer cannot simply fabricate anything whatsoever if he wants it to be recognised by others as a use value, which is to say, to be purchased. Here, it is not merely the biological capacity of the human organism to consume determinate products that is decisive. It is precisely here that the decisive difference between humans and animals lies. In the human being, the process of distinguishing between a useful and a useless thing, which is to say between use value and non-use value, is largely influenced by historical factors. Marx already indicates as much in the previously cited passage: "The discovery ... of the manifold uses of things is the work of history" (MARX, 1976: 125). In Echeverría's exposition of Marx's theory of use value, the concept of history additionally includes geographical 'asynchronies' (in the sense that place, and not only time, also enters into historical factors).

In the comparison of reproduction with communication, it is of great importance that in both processes we find those instances that the founder of semiology distinguishes as "signified" and "signifier", whose unity is represented by the sign. In language, the first represents the "concept" and the second the "acoustic image". The pure concept, however, contains just as few as the pure image; both are, thrown back on their own resources, lost, or to put it more precisely, not imaginable as isolated from each other. So, for example, Saussure suggests that the presumption of a pure concept, without an image, contains the thought that there can exist mature ideas prior to their linguistic expression (ECHEVERRÍA, 1984: 97), a view that he clearly rejects.

Before again broaching the comparison with the production of use values, we must moreover keep in mind the fact that Echeverría, in referring to Walter Benjamin, takes as his point of departure the fact that human beings express themselves and make themselves 
understood not only through languages but also in them, which should be understood to mean that languages are not fixed systems which are merely employed as means of communication, but are created anew and modified with each communicative act. ${ }^{14}$ Echeverría interprets Benjamin's claim as one, which is valid for all sign systems (ECHEVERRÍA, 1984: 44), ${ }^{15}$ but just as every speech-act or speaking ["parole" in Saussure] calls into question the language as a totality ["langue" in Saussure], the same occurs in the production and consumption of use values.

Echeverría understands the unity of the production and consumption of use values in the same way that semiology understands langage [speech], as the faculty of speech, or, in other words, the capacity to make oneself understood in a way that is not chaotic, but nevertheless free. Not free in the sense that completely new signs can be invented at any moment out of nothing, because in this case, in the end, the very functioning of the sign system would be put into doubt, ${ }^{16}$ but at least free enough for us not to communicate merely as animals, according to forms of stimulus and reaction which are fixed by the biological, in the instincts. ${ }^{17}$

14 Echeverría refers here to Walter Benjamin's “Über Sprache überhaupt und über die Sprache des Menschen”: Benjamin, 1966: 10-1. (See ECHEVERRÍA, 1984: 44 n 31).

15 "Like the instrumental field to which it pertains, the code has a history because the process of communication/interpretation is not only fulfilled with it but also in it; because in serving on the evident level, it is itself modified on the profound level. In principle, every time the code is used in the production/consumption of meanings, its project of meaning is put into play and can be at risk of ceasing to be what it is. The project of meaning, which is the establishment of a horizon of possible meanings, can be transcended by another project and move on to constitute the substantial stratum of a new establishment of semiotic possibilities [posibilidades sémicas]. In truth the history of the code takes place as a succession of layers of patterns for meaning, resulting from the refunctionalisation - more or less deep and more or less broad - of earlier projects for new meaning-granting impulses" (ECHEVERRÍA, 1984: 44-5).

In this regard, see moreover a similar reference to the same text by Benjamin elsewhere: “In Benjamin's essay On Language in General and Human Language in Particular an idea predominates which has been central to the history of twentieth-century thought ... human beings do not only speak with a language, using it as an instrument, but, above all, speak in that language ... In principle, in all singular speaking it is the language that is expressed. But also - and with an equal hierarchy - all singular speaking involves that language as a totality. The entire speech [lenguaje] is in play in every individual act of expression; what each of those acts does or ceases to do alters that language in an essential way. The specific language is nothing less than the totalisation of all of these speakings" (from "La identidad evanescente", in ECHEVERRÍA, 1995: 60).

16 Saussure says in this regard: "Language is no longer free, for time will allow the social forces at work on it to carry out their effects. This brings us back to the principle of continuity, which cancels freedom. But continuity necessarily implies change, varying degrees of shifts in the relationship between the signified and the signifier" (SAUSSURE, 1966: 78).

But the moment of the absence of freedom, which Saussure emphasises, only applies to the specific language, the langue, and not to the ability of speaking in its totality (langage or faculté de langage in Saussure's original text in French, speech or faculty of speech in the English translation of Saussure's text, lenguaje or facultad de lenguaje in the Spanish translation of Saussure's text and in Echeverría's article), which was, as we will see below, of significant importance for Echeverría's reflections

17 For the process of production, Marx formulates this difference between animals and humans in the following famous passage: "A spider conducts operations which resemble those of the weaver, and a bee would put many a human architect to shame by the construction of its honeycomb cells. But what distinguishes the worst architect from the best of bees is that the architect builds the cell in his mind before he constructs it in wax. At the end of every labour process, a result emerges which had already been conceived by the worker at the beginning, hence already existed ideally. Man not only effects a change of form in the materials of nature; he also realizes [verwirklicht] his own purpose in those materials. And this is a purpose he is conscious of, it determines the mode of his activity with the rigidity of a law, and he must subordinate his will to it" (MARX, 1976: 284).

42 Comunicações | Piracicaba | v. $24 \mid$ n. $2 \mid$ p. 33-56 | maio-agosto 2017 
So, in the act of producing a use value, we simultaneously find the production of a sign, and it is consumption, its interpretation. Here, we also have a signifier and a signified, which, together, constitute a sign. Echeverría does not tell the reader in a totally unambiguous way which is the signifier and which is the signified in the sign contained in the use value. But in one place, he observes that raw materials tend to come nearer to the signified, and the used instruments of labour nearer to the signifier, but without pigeonholing them definitively. ${ }^{18}$ Rather, it would seem that both raw materials and instruments of labour can possess both functions, but that the second element plays a predominant position in the generation of signs in general. ${ }^{19}$

But the instruments of labour (tools) are distinguished because their effectiveness, in most cases, is not exhausted in a single combined act of production/consumption, as occurs with those use values which are immediately consumed as food. This tendency toward durability in the instrument of labour draws us much closer to a solution to our previously mentioned doubt, since here the parallel with other sign systems becomes clearer, a parallel which up to this point perhaps remained in a degree of obscurity. Just as we do not speak through language but rather in it, we do not produce only through an instrument of labour, but rather in it. On the one hand, in many cases these are of a durable nature but, on the other hand, they are exposed in most cases to the possibility of a constant transformation. In mentioning this, we are not referring only to their wearing out, but to the constantly emerging need (or also the desire arising in the subject) to transform them. As a result, we can broaden the parallel to Saussure's semiology in the sense that every singular act of production (and also of consumption) of a use value is a parole, or speaking, but the totality of these acts in a particular society, ${ }^{20}$ under particular conditions and in a particular historical epoch, can be understood as langue, as language.

18 "Among the means that intervene in productive consumption there are some that only offer it an indication of form for themselves: raw materials or objects of labour; there are others, by contrast, that open up before labour itself an entire set of possibilities for giving form, between which labour can choose for transforming raw materials: these are instruments" (ECHEVERRÍA, 1984: 40-1, italics by S.G.).

19 "The most completed form of the social object is without a doubt that of the instrument. In it, the two tensions that determine all objective forms - the pretension of a form for the subject and his disposition to adopt it - remain in a state of confrontation, in an unstable equilibrium that can be decided differently in each case. The proposition of a formative action on raw materials, inscribed in the instrumental form as a technical structure, not only allows - as in all social objects - but also demands, to be effective, a formative will to action that takes it up and makes it concrete. The general transformative dynamic that the instrument entails must be completed and singularised by labour" (ECHEVERRÍA, 1984: 41).

Echeverría refers, here, to the following passage in Capital: "Living labour must seize on these things, awaken them from the dead, change them from merely possible into real [wirklich] and effective [wirkend] use-values" (MARX, 1976: 289.) Original: "Die lebendige Arbeit muß diese ergreifen, sie von den Toten erwecken, sie aus nur möglichen in wirkliche und wirkende Gebrauchswerte verwandeln" (MARX, 1975: 198).

20 This concept should be clarified precisely, since within a single society there can exist various codes at the same moment. Echeverría speaks elsewhere of "a subjective-objective being, provided with a particular historic-cultural identity..., the historico-concrete existence of the productive and consumptive forces, that is, ... the substance of the nation" (from "El problema de la nación desde la "Crítica de la economía política", in ECHEVERRÍA, 1986: 192-3). 
The problem in the previous reflections (on the question of the "signified" and "signifier") which has not been completely resolved - regarding the relationship between the instrument of labour and the object of labour, ${ }^{21}$ and, therefore, also of the relationship of the tool to raw materials - points to the need to refer to Marx's "theory of the tool" (SCHMIDT, 1971: 103). For Marx, all that which humans find pre-existing on Earth and on which they can work can be considered an "object of labour". Therefore, the Earth in its totality constitutes an "object of labour" for the human beings who inhabit it (MARX, 1976: 284). Here, Marx distinguishes between "objects of labour spontaneously provided by nature", which humans merely "separate from immediate connection with their environment", and "raw material" (MARX, 1976: 284). The "raw material" is differentiated from the "object of labour" in that it has already undergone a treatment which goes beyond mere detachment from nature as a whole, "for example, ore already extracted and ready for washing", which has thus already been "filtered through previous labour" (MARX, 1976: 284). Hence, the concept of the object of labour is broader than that of raw materials. ${ }^{22}$ Evidently, for Marx something analogous happens with the conceptual pairing of "instrument of labour" and "tool":

An instrument of labour is a thing, or a complex of things, which the worker interposes between himself and the object of his labour and which serves as a conductor, directing his activity onto that object. He makes use of the mechanical, physical and chemical properties of some substances in order to set them to work on other substances as instruments of his power, and in accordance with his purposes (MARX, 1976: 285).

But Marx understands the instruments of labour, which have already been transformed by human labour, as "tools". ${ }^{23}$ This concept of the tool as an already-produced instrument of labour can also be found in Benjamin Franklin's definition of the human being as a "tool-making animal". ${ }^{24}$ Marx does not make this distinction between instruments of labour in general and those which are produced - that is, tools - as unequivocally as the previously mentioned distinction between objects of labour in general and those which have been worked, which is to say, raw materials. In any case, Marx repeatedly observes the particularity which characterises the "instruments [of labour] [Arbeitsmittel] ... which

${ }_{21}$ "The simple elements of the labour process are (1) purposeful activity, that is work itself, (2) the object on which that work is performed, and (3) the instruments of that work" (MARX, 1976: 284).

22 "All raw material is an object of labour [Arbeitsgegenstand], but not every object of labour is raw material; the object of labour counts as raw material only when it has already undergone some alteration by means of labour" (MARX, 1976: 284-5).

23 Compare: "As soon as the labour process has undergone the slightest development, it requires specially prpared instruments. Thus we find stone tools [Werkzeug] and weapons in the oldest caves" (MARX, 1976: 284-5).

24 Benjamin Franklin, cited according to Marx, 1976: 286. Elsewhere in Capital, Marx contrasts this definition to that of Aristotle's definition, according to which the human being is "by nature a citizen of a town". While this is "characteristic of classical antiquity", Franklin's definition is "characteristic of Yankeedom". This should not be understood to mean that, in Marx's opinion, Franklin's definition is only valid for the United States, but merely that it goes hand-in-hand with the ideology of that society (MARX, 1976: $444 \mathrm{n}$ 7).

44 Comunicações | Piracicaba $\mid$ v. $24 \mid$ n. $2 \mid$ p. 33-56 | maio-agosto 2017 
have already been mediated through past labour" from those pre-existing instruments of labour which are used just as they were found (MARX, 1976: 286-7). ${ }^{25}$

One explanation of the fact that Marx uses the term "tool" rarely, employing instead "instrument of labour", can consist in the fact that, effectively, today there exist fewer instruments of labour that have yet to be transformed by humans than there exist objects of labour which are still untransformed. Also, in the history of humanity - for example, in the material remains of extinct civilisations - it is easier to demonstrate the use of the latter than the former. While in unelaborated instruments of labour it is possible that, in dropping them after use, they leave no or little trace of that use, it is a different matter with objects of labour which have not been previously worked-upon, since in most cases these form a material part of the final product. In strictly logical terms, it is also correct to substitute the term tool for that of instrument of labour, since "tool" is a subcategory of "instrument of labour", and consequently, every tool is also always an instrument of labour. The problem, here, is that the readers could get confused and create the impression that Marx used the two terms "instruments of labour" and "tool" synonymously. ${ }^{26}$

The consequences of this problem are not immediately serious because Marx, in his analysis, does not study closely those instruments of labour which are not themselves procured through labour, but instead refers almost always in his examples to those which have been produced. ${ }^{27}$ In discussions of the relationship between labour and external nature in Marx's work, some maintain the thesis that Marx himself, in granting primacy to the analysis of value in Das Kapital, implicitly discarded use value as secondary - which is to say, the process of production and reproduction with reference to the natural - and thereby fostered the destruction of nature, practiced by or at least rarely criticised by actually-existing socialism and different forms of Marxism. ${ }^{28}$ This argument does not withstand close inspection if we take into account the high esteem in which Marx holds external nature, which has not been mediated by labour.

According to Alfred Schmidt, Marx's theory of the tool in Das Kapital is that of "the existing, the materialised mediator between the labourer and the object of labour [Arbeitsgegenstand]" (SCHMIDT, 1971: 103). In saying this, he stresses the importance

${ }^{25}$ Among other things, Marx distinguishes between instruments of labour "in general" and those "already mediated by labour," referring to the subcategory of those which, without intervening directly in the labour process, are nevertheless its unconditional premise: "Once again, the earth itself is a universal instrument of this kind, for it provides the worker with the ground beneath his feet and a "field of employment" for his own particular process. Instruments of this kind, which have already been mediated through past labour, include workshops, canals, roads, etc" (MARX, 1976: 286-7, italics by S.G.).

26 Alfred Schmidt also refers to "the instrument of labour, which was for Marx identical with the tool" (SCHMIDT, 1971: 103).

27 See, for example, Marx's mention of the oldest known human instruments of labour, in which he emphasises their character as a tool, that is, their having been made available previously through human labour: "domesticated animals, i.e. animals that have undergone modification by means of labour, that have been bred specially, play the chief part as instruments of labour along with stones, wood, bones and shells, which have also had work done on them" (MARX, 1976: 285-6, italics by S.G.).

${ }_{28}$ On this discussion, see moreover Alfred Schmidt's prologue to the most recent edition of his book on the concept of nature in Marx (SCHMIDT, 1993: I-XVII). 
of tool-making for the entirety of human development, and above all the development of human intellectual capacities: "There can be hardly any doubt that the most basic abstractions have arisen in the context of labour-processes, i.e. in the context of tool-making" (SCHMIDT 1971: 102).

In this sense, Echeverría's attempt to see a parallel between the processes of production and communication stands in the non-dogmatic Marxist tradition, above all if we bear in mind the fact that after the 'linguistic turn' in idealist and related philosophies, the concept of spirit or reason was generally substituted by that of communication or discourse. To the question of whether or not Echeverría's attempt makes him an idealist philosopher, we could respond that in such matters a separation cannot always be established with the kind of clarity we find in the textbooks of dogmatic Marxism. In this context, it is worth emphasising the close consistency between Hegel and Marx regarding the theory of the tool. In this respect, Schmidt underlines Hegel's contribution to understanding the tight relationship between the development of tools and the human capacity for communication:

\begin{abstract}
Hegel, as well as Marx, was aware of the historical interpenetration of intelligence, language and the tool. The tool connects man's purposes with the object of his labour. It brings the conceptual element, logical unity, into the human mode of life. Hegel wrote in the Jenenser Realphilosophie [the Jena manuscripts]: "The tool is the existent rational mean, the existent universality of the practical process; it appears on the side of the active against the passive, is itself passive in relation to the labourer, and active in relation to the object of labour" (SCHMIDT 1971: 102). ${ }^{29}$
\end{abstract}

It is precisely in Hegel's linking of the processes of production and communication in his formulations on the tool that Schmidt sees Hegel's importance for historical materialism. ${ }^{30}$ Incidentally, this importance of Hegel for the Marxian theory of the tool is recognised by Marx himself. In his discussion of the tool in Capital, Marx cites Hegel's understanding of the "cunning of reason" in an effort to understand philosophically the "cunning of man" in the use of tools (SCHMIDT, 1971: 105), as Schmidt describes it in summarising Marx. The human being - Marx writes - "makes use of the mechanical, physical and chemical properties of some substances in order to set them to work on other substances as instruments of his power, and in accordance with his purposes" (Marx, 1976: 285). In a footnote inserted at this point in Capital, Marx immediately quotes the following well-known phrase from Hegel's Logic:

Reason is as cunning as it is powerful. Cunning may be said to lie in the intermediative action which, while it permits the objects to follow their own bent and act upon one another till they waste away, and does not itself directly inter-

29 Here Schmidt cites Hegel, 1932: 221.

30 Schmidt notes: "Lenin stated correctly that Hegel was a precursor of historical materialism because he emphasised the role played by the tool both in the labour-process and in the process of cognition" (SCHMIDT, 1971: 105).

46 Comunicações | Piracicaba | v. 24 | n. 2 | p. 33-56 | maio-agosto 2017 
fere in the process, is nevertheless only working out its own aims (HEGEL, 1986: §209, appendix: 365.) $)^{31}$

Despite this direct reference by Marx to Hegel in the context of his theory of the tool, we must note an important difference between the two philosophers. Alfred Schmidt draws attention to the fact that "Marx had a far lower estimation" of the tool than did Hegel (SCHMIDT, 1971: 104). The latter viewed the ends of production as subordinated to its means, since the end is finite, and, therefore, "it is not an absolute, nor simply something that in its own nature is rational" (HEGEL, 2002: 747). The tool, on the contrary, as the "means is superior to the finite ends of external purposefulness: the plough is more honourable than are immediately the enjoyments procured by it and which are ends" (HEGEL, 2002: 746). ${ }^{32}$ On the contrary, for Marx the tool is not something completely extrinsic to the product, and nor does he subordinate the latter to the former in terms of its capacity to immediately satisfy human needs, as does Hegel; while for Hegel the presumed durability of tools situates them on a higher level vis-à-vis those products which are extinguished in consumption, ${ }^{33}$ Marx - here moving completely within the materialist tradition, which was generally far from asceticism and opposed to it - "had no intention of deriving any arguments against the satisfactions of the senses from their transitory nature" (SCHMIDT, 1971: 104).

Moreover, the relative durability of tools, a trait which according to Hegel distinguishes them from products, is not always a given. Alfred Schmidt understands the Marxian definition of the tool as a "mediator between labour with a definite aim and its object", and setting out from this, he distinguishes "three forms of tool" (SCHMIDT, 1971: 103): "The tool can maintain itself in its identical form, it can enter materially into the produce of labour and, finally, it can be completely consumed, without becoming part of the product of labour" (SCHMIDT, 1971: 103).

It is evident that of these three types of tool, Hegel knows only the first. If Schmidt understands this as a limitation of the dialectical idealist's understanding of the tool, he clarifies that "it had an element of truth in it, in that most tools remain the same in use, and are foreign to their product" (SCHMIDT, 1971: 103). In this respect, Hegel has limited his philosophical reflection to the predominant form of tool. In any case, we can see the degree

31 Hegel cited according to Marx, 1976: 285 n 2.

Compare, moreover, Hegel's observations which precede his reflections on tools in the Logic: "That the end relates itself immediately to an object and makes it a means ... may be regarded as violence ... But that the end posits itself in a mediate relation with the object and interposes another object between itself and it, may be regarded as the cunning of reason" (HEGEL, 2002: 746).

32 The immediate philosophical relationship between Hegel's Logic and Marx's Capital gets lost for the reader in English on account of the different ways in which the German term "Mittel" is translated: in the Logic's case as "means", and in Capital as "instrument", for example in the case of the central Marxian concept of 'Arbeitsmittel' translated by Fowkes in one of the most popular English editions of Capital as "instrument of labour", instead of "means of labour".

33 "The tool lasts, while the immediate enjoyments pass away and are forgotten. In his tools man possesses power over external nature, even though in respect of his ends he is, on the contrary, subject to it" (HEGEL, 2002: 747). 
to which the materialist Marx grasps reality better than Hegel, moreover, in the fact that he understands just how relative the conceptual determinations of these various objects with regard to their position in the labour process are ${ }^{34}$ This is no small thing, since their durability and perishability are also merely relative qualities with reference to other components of the labour process, and are not absolute as Hegel suggests with his categorical judgment that those components which do not constitute tools "pass away and are forgotten" (HEGEL, 2002).

At this point, we can return to Bolívar Echeverría's studies on the role of use value in the process of reproduction and on the possible application of the semiology categories of "signifier" and "signified" to this process and its objects. The above-mentioned vagueness as to whether the tool constitutes the signifier and the raw material the signified should be discussed as follows. At first glance, the response to this question would be the following: the tool is the signifier, the raw material the signified. But with this we would come too close to Hegel's concept of the tool, not only in his tendency to establish a hierarchy between tool and raw material, but moreover the danger of favouring a static assignment (which we just criticised) of specific components of the process of reproduction to some pre-given role.

Certainly, we could say that the Hegelian conception could grasp these components again at any moment of production, and that insofar as his philosophy is dialectical, he ought to be able to understand conceptually the double form of objects. However, Hegel's emphatic discourse on the tool as the "more honourable" and his disparaging valorisation of consumption indicate a static element in his theory. The concept of "productive consumption" (MARX, 1976: 290), which is central for Marx and indicates precisely the difficulty of fixing determinate elements of reproduction on one factor and in one static form, as does Hegel, is unfamiliar to the great dialectician, who, in his turn, gave Marx important indications for his theory of the tool.

The fact that Echeverría scarcely touches on the question of signifier and signified in social reproduction (and in the end, leaves this question unresolved) could, therefore, be interpreted as follows: Echeverría perceives the concomitant danger of an idealist reduction of the Marxian theory of the tool and of reproduction. He wants to enrich or make more comprehensible the Marxian theory of use value through the semiology approach, while simultaneously avoiding the possibility of an idealistic softening of the Marxian critique.

At this point, the reader might be asking himself: and all this, what is it good for? What does this confrontation of the production and consumption of use values with semiology clarify that could not be clarified in some other manner? To such a question, we see two possible responses: on the one hand, Echeverría's recourse to the semiology approach

34 "Hence we see that whether a use-value is to be regarded as raw material, as instrument of labour or as product is determined entirely by its specific function in the labour process, by the position it occupies there: as its position changes, so do its determining characteristics"; and "Again, a particular product may be used as both instrument of labour and raw material in the same process. Take, for instance, the fattening of cattle, where the animal is the raw material, and at the same time an instrument for the production of manure" (MARX, 1976: 288-9).

48 Comunicações | Piracicaba | v. 24 | n. 2 | p. 33-56 | maio-agosto 2017 
should be understood as polemical. In understanding the production and consumption of use values as the most fundamental of semiology systems, he is taking the wind out of the sails of those theoretical currents which, without the least consideration, declare spoken language to be the most important of human sign systems. We must, then, liberate semiology from the slavery into which it has fallen, after Ferdinand de Saussure, at the hands of linguistics, and as the mere supplier of the latter:

... do you see it like these 'radical' discourse theorists, for whom the only thing that exists is discourse?

No, to the contrary; precisely against this tendency of the most radical structuralism, I tried to disconnect semiology from structuralism as far as possible and integrate it into Marx's conceptual apparatus. ${ }^{35}$

On the other hand, we could give the following answer to the same question: through the combination of Marxian theory with Saussure's semiology, Echeverría seeks to oppose a specific interpretation of the former. According to this interpretation, what is decisive in the relations of production is the value side of production; on the basis of this, we can explain and evaluate everything else, which is to say, including the use value side of production. This view results in the fact that the use values produced in the framework of a society in which there exists a relatively high degree of industrialisation will lead them to be automatically conceived as 'more developed' than others. And, moreover, since it is known that use values are in every case connected with the cultural constitution of a country, one can draw the conclusion that particular cultural forms are 'more developed' than others merely because they are found in a region in which a higher degree of industrialisation reigns than in other regions. Even if there are ever fewer theories explicitly defending such a view in an aggressive manner, this is, nevertheless, implicitly the prevailing view in everyday life as in the sciences. The fact that it is not proclaimed all the time does not for a moment undermine its almost absolute omnipresence between the lines.

One example from everyday life in Mexico would be the predilection of the urban middle class for white bread, above all sliced bread for toasting ['pan bimbo']. From a medical and nutritional perspective, such bread has an incomparably inferior use value to corn tortillas, which are more common among the poor population in fulfilling the same function of accompanying meals. But as white bread is identified with a culture that has become predominant due to a more powerful development of productive forces (and with these, weaponry as well) and due to its empires - who with this development were thus in a position to dominate more than one continent - the middle class set out from the idea that nothing beats white bread. Even though the motives that are explicitly formulated for this choice may be different on any given occasion, that does not in the slightest degree alter the foundation of this preference. ${ }^{36}$

35 Interview with Bolívar Echeverría, cassette I, side A, pos. 258-65.

36 'It's just that white bread tastes better', they say, which is true for some reason; many things taste better when in the vicinity of the powerful. 
But we can also observe the same mechanism on the theoretical and political planes. Since the term 'underdeveloped countries' came under critique, these are now referred to as 'developing countries', or very fashionably as 'emerging countries'; however, it remains clear in which direction their aspiration points and to what they are aspiring, namely the threshold that must be crossed with the utmost haste: that leading to the 'first world', which also implies subordination to the cultural forms that prevail there. All of this terminology is not typically Marxist, although it also appears frequently at the heart of Marxist debates. In this form - lightly concealed - what prevails is the idea that sooner or later all human beings should live as the inhabitants of Europe and the United States live today, and that this will represent true 'development'. A fixation on the production and consumption of values, alongside a naïve progressivism, form an ideological breeding ground in which Eurocentrism is unlikely to cease to flourish.

It is even the case that political groups which consider themselves to be very much above such discussions, tend to be stuck up to their neck in them, although without wanting to realise it. But this becomes evident when their members arrive in peripheral countries and immediately protest when things move differently in local leftist organisations than they do in their country of birth, quickly suspecting that the level of local discussion has not flourished to the same extent as in the refuge of truth: Europe. The same can be said, in reverse, for Latin America, where for example many people on the Left yearn for nothing more than to travel to Europe in order to get to know as closely as possible the projects, theories, and discussions underway there. At the same time, the Mexican Left, for example, for the most part attempts - in some way similarly to the other national political currents to imitate with the utmost perfection those European political tendencies to which they are similar, and in the best of cases to 'apply' their projects and ideologies to Mexico. ${ }^{37}$

On the contrary, the serenity with which Saussure places the many existing languages side-by-side, without undertaking the effort to establish hierarchies between them, is without a doubt what Echeverría appreciates in his work. And Echeverría imagines something similar for use values: a sort of analysis which does not begin by considering some better than others merely on account of having emerged within the framework of a more industrialised form of value creation. In this context, it would also be interesting to study, without establishing hierarchies, the various existing regional forms of living and moving about intellectually in capitalist everydayness.

The application of Ferdinand de Saussure's semiology to the theory of use-value therefore has the following facet: alongside langue [language in English, idioma in Spanish], that is to say, the totality of multiple productions and consumptions of use values in a particular historical constellation, there exists moreover the general langage or faculté de langage [speech or faculty of speech in English, lenguaje, or capacidad de hablar in Spanish]. This is the fundamental point. What is specifically human - that is the question

37 The fact that the most diverse set of political tendencies have inscribed 'nationalism' on their flags does not change in the least their mimicry of the political models of the so-called First World. Nationalism itself is a typically European invention.

50 Comunicações | Piracicaba | v. 24 | n. $2 \mid$ p. 33-56 | maio-agosto 2017 
in Echeverría's article "La 'forma natural' de la reproducción social", and it is not langue (a particular language) but rather langage, the faculty of speech in and of itself. What distinguishes human beings and their self-creation is not a specific form of use values that are made and used, but the very capacity to do so at all.

With the distinction of language from speech (faculty of speech) and the application of this distinction to the sphere of production, we can no longer arrive so easily at the conclusion that a determinate constellation of use values exists in a state of 'superior' or 'inferior' development. Similarly, if we compare, for example, French to German, we cannot reasonably say that one is 'superior' to the other. So, in Saussure's theory, the things discussed are ones in which Marxist theories do not feature. Thus the Swiss Saussure speaks with an almost insurmountable naturalness about the "differences among languages and ... the very existence of different languages" (SAUSSURE, 1966: 68).

For him, there is absolutely no possibility of discussing whether a language is more valuable than another, or something of the like. Such questions absolutely do not exist for him. ${ }^{38}$ This is what Saussure's semiology and linguistics can teach us: what unifies humans is not their common language, but rather the common faculty of speech they share. Or, better put, their capacity to understand one another through signs, and in this speech is but one of many forms, the fundamental form being the production and consumption of use values.

So Echeverría's interest in Saussurean semiology can be understood as a theoretical auxiliary for combating "false universalism", which is nothing more than the self-elevation of one existing particularity to the status of 'general' (for example, the self-elevation of European culture to the status of human culture in general), and to do so without falling into a general whatever-ism. This is not to say that no universal exists, as many tend to argue today; a universal factor that unites human beings does, indeed, exist, but it is one which allows within itself the most diverse of forms. This is the faculty of speech in its broadest sense, as discussed above, with the possibility that this entails (and realises) of the formation of the most diverse sign systems, which is to say, in other words, the most diverse ways of organizing everyday life, assuring reproduction through the most diverse sorts of use values.

Elsewhere, in the article "La identidad evanescente" ["The Evanescent Identity"] Echeverría formulates a similar idea with regard to the non-Eurocentric approaches of Wilhelm von Humboldt, the founder of comparative philology, in the sense that beyond false and abstract Eurocentric universalism there can also exist a "concrete universalism" in which subjects - individual as well as collective - are fully conscious of the need for the 'other', be it inside or outside themselves. The "concrete universalism of a humanity which is at the same time unitary and unconditionally plural" (ECHEVERRÍA, 1995: 59), which is possible in principle in modernity, has, nevertheless, been impossible, due to the

38 Here we will not go into where Saussure's position comes from. What is surprising, both in the cited passage as in others, is that as a general rule he derives his examples from French and German. In the history of Switzerland, we witness a process uncommon in Europe in the stability of its multilingual system which has not seen successful attempts to raise one language (French, Italian, Romansh, or German) into a position of dominance over the others, on the basis if it being purportedly 'better' or 'more developed'. 
previous and present capitalist form of modernity and due to the "artificial scarcity" which it necessarily produces (ECHEVERRÍA, 1995: 59). ${ }^{39}$ This concrete universalism is already delineated in the history of European theory, but only in the "self-critical dimension of European culture".

Echeverría writes: "Humboldt's Sprachphilosophie ... sought the general human [lo humano] more in the very capacity for symbolisation or 'codification' ... than in a specific result of certain particular symbolisations" (ECHEVERRÍA, 1995: 57). ${ }^{40}$ Here, the vast gulf separating Bolívar Echeverría from the central tendencies of so-called postmodern theories becomes obvious. He is not interested in a simple condemnation of the concept of universalism, but rather a critique of the prevailing false universalism, which is abstract in nature, in favour of a "concrete universalism" that takes as its point of departure that which all humans hold in common and which thus represents the possibility of their coexistence, while recognising at the same time the various different cultures and forms of life, without falsely (which is to say, abstractly) establishing hierarchies in that universalism in the sense of less or more developed forms of some general human culture - which is always, of course, that of the conquerors.

At this point, it would be worth asking, certainly, why it is that Echeverría does not refer to Marx himself for this critique of false universalism. Is it not possible to deal with the Eurocentric interpretations of Marx - as dominant as these may be within Marxism - on the basis of Marx himself, if we understand his critique of the capitalist mode of production as precisely a critique of the false universalisation that stands as its foundation? On the one hand, all human beings are themselves equated in the act of equating their products (for the purpose of being freely interchangeable); but, in any case, this is transformed into the root of the greatest form of inequality, that which exists between those who own the means of production and those who have nothing to sell except their labour power. ${ }^{41}$

39 Echeverría refers explicitly to Marx, here, and writes: "from an instrument of abundance, the technical revolution becomes, in the hands of capitalism, a generator of scarcity" (ECHEVERRÍA, 1995: 59). This is necessary to maintain the capitalist mode of production, which functions only on the basis of exploiting the labour of others and, in turn, requires a general scarcity that, according to Marx, and followed on this point by Echeverría and other serious economists, under current technical conditions can only be guaranteed artificially (ECHEVERRÍA, 1995: 59). In this respect, Capital Vol. I, Chapter 15, "Machinery and Large-Scale Industry": Marx, 1976: 492 ff.

40 "Sprachphilosophie" means "philosophy of language".

41 Marx emphasises his critique of the concept of equality in the "Critique of the Gotha Programme", which could be read here as a critique of what Echeverría calls "abstract universalism":

"In spite of this advance [in the proposals of the Gotha programme], this equal right is still constantly stigmatised by a bourgeois limitation. The right of the producers is proportional to the labour they supply; the equality consists in the fact that measurement is made with an equal standard, labour.

But one man is superior to another physically, or mentally, and supplies more labour in the same time, or can labour for a longer time; and labour, to serve as a measure, must be defined by its duration or intensity, otherwise it ceases to be a standard of measurement. This equal right is an unequal right for unequal labour. It recognizes no class differences, because everyone is only a worker like everyone else; but it tacitly recognizes unequal individual endowment, and thus productive capacity, as a natural privilege. It is, therefore, a right of inequality, in its content, like every right. Right, by its very nature, can consist only in the application of an equal standard; but unequal individuals (and they would not be different individuals if they were not

52 Comunicações | Piracicaba | v. 24 | n. 2 | p. 33-56 | maio-agosto 2017 
The problem, here, is the following: even when the Eurocentrism of "bourgeois stupidity" provokes disgust in Marx, ${ }^{42}$ neither he nor Engels are always free of it, for example, when they say that countries like Mexico could experience nothing better than an occupation by the United States since this would finally make them a participant in a certain kind of development (which is, of course, 'universally human'). Just as in the problem of anti-Semitism, here we can find a contradiction internal to Marx's work. From his basic approach, his work is extremely critical toward the bourgeois abstract conception of equality, and he analyses not only the mendacity expressed in the bourgeois ideology of equality, but also the problematic of the idea of equality in general (which is also expressed in his rare mentions of communism, in thinking that an emancipated society is precisely that in which everyone receives according to his needs and gives according to his capacities, with which the very idea of human equality perishes). But in isolated cases, remnants of bourgeois thought do occasionally raise their head, including some of Eurocentric orientation.

It is worth noting, here, how sharply certain parts of the Left - above all, its dogmatic forms - have chosen and brought together precisely those leftovers of bourgeois thought still stuck to the Marxist approach, much as pieces of shell stick to baby chicks who have just broken out of the egg, in order thereby to justify their own ideas 'in a Marxist fashion'. For many Marxists, Marx was too huge, and his thought too radically counter posed to prevailing thinking, to be truly grasped after having read a fifteen-page handbook; or it was too radical to be easily convincing outside of a revolutionary situation. In order to escape this awful tradition (and this is our second explanation), Echeverría attempts to take up again other theories as well, for example semiology.

In this context Bolívar Echeverría can be distinguished - despite all the similarities - from Western Marxism and the Frankfurt School. Thus, for example, while the critique

unequal) are measurable only by an equal standard insofar as they are brought under an equal point of view, are taken from one definite side only -- for instance, in the present case, are regarded only as workers and nothing more is seen in them, everything else being ignored. Further, one worker is married, another is not; one has more children than another, and so on and so forth. Thus, with an equal performance of labour, and hence an equal in the social consumption fund, one will in fact receive more than another, one will be richer than another, and so on. To avoid all these defects, right, instead of being equal, would have to be unequal". Marx's critique of the adoption by social democracy of bourgeois presumptions of equality and justice then leads up to the phrase, his most famous aside from the eleventh thesis on Feuerbach, on the possible slogan for a "higher phase of communist society": "From each according to his ability, to each according to his needs!" (MARX, 1970: 13 ff.)

42 On Marx's rejection of bourgeois ethnocentrism, see his critique of Jeremy Bentham, or as he refers to him, "that soberly pedantic and heavy-footed oracle of the 'common sense' of the nineteenth-century bourgeoisie": 'Bentham does not trouble himself with this. With the dryest naïveté he assumes that the modern petty bourgeois, especially the English petty bourgeois, is the normal man. Whatever is useful to this peculiar kind of normal man, and to his world, is useful in and for itself. He applies this yardstick to the past, the present and the future. The Christian religion, for example, is "useful", "because it forbids in the name of religion the same faults that the penal code condemns in the name of the law". Art criticism is "harmful" because it disturbs worthy people in their enjoyment of Martin Tupper, etc. This is the kind of rubbish with which the brave fellow, with his motto "nulla dies sine linea", has piled up mountains of books. If I had the courage of my friend Heinrich Heine, I should call Mr Jeremy a genius in the way of bourgeois stupidity" (MARX, 1976: 758-9 and n 51). 
and analysis of Dialectic of Enlightenment admittedly mentions "European civilisation" as the central object of the investigation, its ethnocentric character is not taken as a theme (HORKHEIMER and ADORNO, 2002: 9). Neither in its scientific behaviour or its interests has the Frankfurt School been able to remove itself from common Eurocentric prejudice, and it has largely ignored authors from the so-called Third World.

But despite these circumstances, this theoretical focus has elements that can be useful for a critical theory of Eurocentrism and racism. We could realise this in various seminars given in Mexican universities where, for example, reading the chapter about "Elements of Anti-Semitism" of the aforementioned book provoked revealing discussions regarding internal racism within Mexico - almost always targeting indigenous people - which duplicates the effects of Eurocentrism in the country, and as a result the text has been taken as a theoretical foundation for research on this topic. There are, of course, serious differences between anti-Semitism and racism against indigenous people, but combining a critique of the naïve belief in enlightenment with an analysis of the causes of the persecution of Mexican minorities is so stimulating precisely because also in Mexico the idea is very widespread that an application of the ideals of the French Revolution can resolve all the country's ills almost miraculously. But if we recognise that it is not an 'incomplete modernity' that stokes racism, but, instead, that this racism brings modernity to its perfect expression in its own contradiction, this could help us to avoid errors in Mexico before they are committed with the same perfection as they were in Europe. This aspiration to imitate the errors of 'European civilisation' is actually the common denominator of both the Left and of conservatives in Mexico, and is described as the 'modernisation' and 'democratisation' that is demanded and sometimes celebrated by all.

The philosophical contributions of Bolívar Echeverría for a possible Critical Theory from The Americas, discussed in this article, as well as his other contributions, which should be discussed widely soon, could help in a special way to overcome the problematic practical and theoretical limitation for the imperative emancipation of the human beings from exploitation, exclusion and repression from other human beings (GANDLER, 2016). Only overcoming at all levels the capitalist way of international socialisation, and confronting it with a international critical community, which includes as a central task a real international theoretical debate, it will be possible to stop the false existing image that the right wing movements produce from themselves, to allegedly the only way of contesting the existing social contradictions with "new" nationalisms (Brexit dixit), "new" xenophobia and "new" exclusions of everybody and everything, seeming to be strange. It is not enough to criticise the right-wing production of this aggressive idea of the "strange", but it is necessary to let behind the own closed mind, which until today exists even in the critical socio theoretical discussions, when they ignore the powerful contributions for a Critical Theory from The Americas and from other regions, that seem to be "far away". 


\section{REFERENCES}

BENJAMIN, W. 1966. "Über Sprache überhaupt und über die Sprache des Menschen." in W. Benjamin. Angelus Novus. Ausgewählte Schriften 2. Frankfurt am Main: Suhrkamp. BUNDSCHUH, S. 1998. 'Und weil der Mensch ein Mensch ist...' Anthropologische Aspekte der Sozialphilosophie Herbert Marcuses. Lüneburg: Zu Klampen.

ECHEVERRÍA, B. 1968. "Einführung.” in Guevara, 1968.

. 1977a. "Para lectores de El Capital." Investigación Económica. Revista de la Facultad de Economía, 1: 265-9.

. 1977b. "Esquemas gráficos para el estudio del capítulo quinto de El Capital." Investigación Económica. Revista de la Facultad de Economía, 4: 237-46.

. 1984. "La 'forma natural' de la reproducción social." Cuadernos Políticos, 41: $33-46$.

1986. El discurso crítico de Marx. Mexico City: Era.

. 1995. Las ilusiones de la modernidad. Mexico City: UNAM/El Equilibrista.

Gandler, S. 2016 [2015]. Critical Marxism in Mexico. Adolfo Sánchez Vázquez and Bolívar Echeverría. Chicago: Haymarket.

HEGEL, G.W.F. 1932. Jenenser Realphilosophie. Leipzig.

. 1986. Enzyklopädie der philosophischen Wissenschaften. Erster Teil. Die Wissenschaft der Logik, Vol. 8 of Werke, in 20 volumes, compiled on the basis of his works from 1832 to 1845 . Edited by E. Moldenhauer and K.M. Michel, Frankfurt am Main: Suhrkamp.

. 2002. Science of Logic. London: Routledge.

HJELMSLEV, L. 1971 [1954]. "La stratification du langage." in Essais linguistiques. Paris: Minuit.

HORKHEIMER, M. and Th.W. Adorno. 2002. Dialectic of Enlightenment: Philosophical Fragments. Stanford, CA: Stanford University Press.

JAKOBSON, R. 1960. "Closing Statement: Linguistics and Poetics.” in T.A. Sebeok (ed.) style and language. New York: Wiley.

. 1971. "Two Aspects of Languages and Two Types of Aphasic Disturbances." in R. Jakobson. Selected Writings, II: World and Language. The Hague: Mouton.

KORSCH, K. 1965. "10 Thesen über Marxismus heute.” Alternative. Zeitschrift für Literatur und Diskussion, 8, 41. 
LEROI-GOURHAM, A. 1964. Le geste et la parole, I: Technique et langage. Paris: A. Michel.

MARX, K. 1904. contribution to the critique of political economy. Chicago: Charles Kerr. lishers.

1954. Capital. A Critique of Political Economy, Vol. I. Moscow: Progress Pub. 1970. "Critique of the Gotha Programme." in K. Marx and F. Engels. Selected Works, Vol. III, Moscow: Progress Publishers.

. 1975. Das Kapital, Vol. I. in K. Marx F. and Engels. Werke, Vol. 23. Berlin: Dietz. . 1976. Capital: A Critique of Political Economy, Vol. I. London: Penguin.

SAUSSURE, F. 1966. Course in General Linguistics. New York: McGraw-Hill.

SCHMIDT, A. 1971 [1962]. The Concept of Nature in Marx. London: NLB.

. 1993. Der Begriff der Natur in der Lehre von Marx. Hamburg: Europäische Verlagsanstalt.

TROUBETZKOY, N.S. 1970. Principes de Phonologie. Paris: Klincksieck.

DAdos do AUTOR

\section{Stefan Gandler}

Doutor em Filosofia pela Universidade de Frankfurt. Coordenador desde 2012, o Corpo Acadêmico “A globalização, modernização, desenvolvimento e região.” México. email@ provedor.com

Submetido em: 17-4-2017

Aceito em: 2-6-2017 